\title{
Heterogeneity of Genome Sizes within the Genus Spiroplasma
}

\author{
P. CARLE, ${ }^{1}$ F. LAIGRET, ${ }^{1 *}$ J. G. TULLY, ${ }^{2}$ AND J. M. BOVÉ ${ }^{1}$ \\ Laboratoire de Biologie Cellulaire et Moléculaire, Institut National de la Recherche Agronomique, and Université de \\ Bordeaux II, 33883 Villenave d'Ornon Cedex, France, ${ }^{1}$ and Mycoplasma Section, Frederick Cancer Research and \\ Development Center, National Institute of Allergy and Infectious Diseases, Frederick, Maryland 21702 2
}

\begin{abstract}
Organisms belonging to the genus Spiroplasma are currently classified into 23 groups, 17 of which have been assigned species epithets. We determined the genome sizes of representatives of 20 groups by using pulsed-field gel electrophoresis. Each genome size was deduced from the mobility of linear nonrestricted DNA, as well as from the sum of the sizes of restriction fragments obtained after digestion with $N o t I$, a restriction endonuclease with a limited number of restriction sites in spiroplasma DNA. The values which we obtained indicated that the genome sizes of members of the genus Spiroplasma range from 940 to 2,220 kbp.
\end{abstract}

Organisms belonging to the class Mollicutes are among the simplest self-replicating organisms known. These wall-less eubacteria are characterized by small genomes that have low DNA guanine-plus-cytosine $(\mathrm{G}+\mathrm{C})$ contents. The class Mollicutes is currently divided into eight genera: Asteroleplasma, Anaeroplasma, Acholeplasma, Entomoplasma, Mesoplasma, Spiroplasma, Mycoplasma, and Ureaplasma (36).

Measurement of the genome sizes of bacterial species has been greatly facilitated by the development of pulsed-field gel electrophoresis (PFGE) (32). This technique, associated with restriction enzyme digestion and Southern blot hybridization, has made it possible to obtain physical and genomic maps of numerous bacterial species $(33,34)$. PFGE has been used to determine the genome sizes of several mollicute species $(9,13$, $14,19,21,24,26,28,29,35,39,41,49,52,53)$. A continuum of sizes has been found, ranging from $580 \mathrm{kbp}$ for the smallest genome, the Mycoplasma genitalium genome $(9,35)$, to 1,820 kbp for the largest genome, the Spiroplasma citri genome (53).

Spiroplasma citri, the causative agent of citrus stubborn disease, was the first Spiroplasma species to be described (30). Today, numerous spiroplasmas have been isolated from plants and arthropods, mainly insects (50). An approach to spiroplasma classification based on serologic relatedness data, electrophoretic patterns of proteins, G+C DNA contents, and levels of DNA-DNA homology was first proposed in 1980 (18). Up to 1993,24 groups were recognized $(3,15,37)$ but recently, the group XVII spiroplasmas have been shown to be members of group VIII (12); thus, group XVII contains no organisms at the present time. Groups may be divided into subgroups on the basis of DNA-DNA homology, serological relatedness, and host range data (44).

Previously, the genome sizes of the following Spiroplasma species have been determined: Spiroplasma citri (1,820 kbp), Spiroplasma apis (1,350 kbp), Spiroplasma melliferum (1,460 $\mathrm{kbp})$, Spiroplasma insolitum (1,850 kbp), Spiroplasma clarkii $(1,770 \mathrm{kbp})$, and Spiroplasma monobiae (940 kbp) $(13,16,47$, $48,52,53)$. In this study we determined, by using PFGE, the genome sizes of representatives of all spiroplasma groups except groups II, XIV, and XXIII. We also determined the genome sizes of representatives of all eight subgroups of group I.

Spiroplasma strains and cultivation procedures. All of the

\footnotetext{
* Corresponding author. Mailing address: Laboratoire de Biologie Cellulaire et Moléculaire, INRA et Université de Bordeaux II, BP81, 33883 Villenave d'Ornon Cedex, France. Phone: 33.56.84.31.50. Fax: 33.56.84.31.59. Electronic mail address: laigret@bordeaux.inra.fr.
}

spiroplasma strains which we studied (Table 1) were grown in $100 \mathrm{ml}$ of SP4 or MIA medium (43).

Genome size determination. Cultures at the late log phase of growth were incubated with $100 \mu \mathrm{g}$ of chloramphenicol per ml for $90 \mathrm{~min}$ at $37^{\circ} \mathrm{C}$ in order to complete ongoing rounds of replication and to prevent the initiation of new rounds. The cells were then collected by centrifugation for $30 \mathrm{~min}$ at 20,000 $\times g$.

The pelleted cells were embedded in LMP agarose (Geneline; Beckman, Palo Alto, Calif.) and were treated as described previously (27), except that the cellular pellet was resuspended in STE (100 mM NaCl, $10 \mathrm{mM}$ Tris- $\mathrm{HCl}, 1 \mathrm{mM}$ EDTA [pH 8.0]) instead of phosphate-buffered saline (53). Genome sizes were determined by using full-length (nonrestricted) chromosomes that were linearized by random breakage during the extraction procedure (14). In addition, restriction enzyme Not I was used as recommended by the manufacturer (New England Biolabs, Beverly, Mass.). Electrophoresis was performed with a Geneline II apparatus (Beckman) by using a transverse alternating field electrophoresis system and Tris-borate-EDTA as the running buffer. With the exception of nonrestricted genomic DNA from Spiroplasma ixodetis $\mathrm{Y}_{32} 2^{\mathrm{T}}(\mathrm{T}=$ type strain), the genomic linear molecules and NotI restriction fragments were separated on a $1 \% \mathrm{LE}$ agarose gel (Beckman) under the following electrophoresis conditions: $370 \mathrm{~mA}$; three steps of $12 \mathrm{~h}$ each, with pulse times of 1,2 , and $3 \mathrm{~min} ; 8^{\circ} \mathrm{C}$. The sizes of the resulting fragments were evaluated by comparing them with Saccharomyces cerevisiae chromosomal DNA fragments ranging in size from 215 to $2,200 \mathrm{kbp}$ (Bio-Rad, Hercules, Calif.) and lambda phage DNA concatemers (New England Biolabs). For Spiroplasma ixodetis $\mathrm{Y}^{2} 2^{\mathrm{T}}$, nonrestricted genomic DNA was subjected to PFGE on a $0.6 \% \mathrm{LE}$ agarose gel by using the conditions described above, except that there was an additional step of $9 \mathrm{~h}$ with a pulse time of 4 min. In this case, the size of the genomic DNA was determined by comparing its mobility with the mobilities of chromosomes obtained from Candida albicans (1,010 to 3,000 kbp) and Saccharomyces cerevisiae ( 215 to $2,200 \mathrm{kbp}$ ).

The genome sizes of the spiroplasmas which we examined are shown in Table 2. For most of the spiroplasma genomes, a single band was obtained after digestion with NotI, indicating either that there were no sites for this enzyme or that a single site was present. For two spiroplasmas, Spiroplasma sp. strain EA1 and Spiroplasma sabaudiense AR- $1343^{\mathrm{T}}$, three bands were obtained after digestion with Not I, indicating that there were three restriction sites for Not $\mathrm{I}$.

In every case, the genome size estimated from Not I digestion 
TABLE 1. Spiroplasmas whose genome sizes have been determined

\begin{tabular}{|c|c|c|c|c|}
\hline $\begin{array}{l}\text { Group or } \\
\text { subgroup }\end{array}$ & Species or trivial name & Strain(s) & Principal host(s) & Reference \\
\hline $\mathrm{I}-1$ & Spiroplasma citri & $\mathrm{R} 8 \mathrm{~A} 2^{\mathrm{T}}=\left(\mathrm{ATCC} 27556^{\mathrm{T}}\right)$ & Citrus leafhoppers & 30 \\
\hline $\mathrm{I}-2$ & Spiroplasma melliferum & $\mathrm{BC}-3^{\mathrm{T}}=$ ATCC $33219^{\mathrm{T}}$ ) & Apis mellifera & 8 \\
\hline $\mathrm{I}-3$ & Spiroplasma kunkelii & $\mathrm{E}-275^{\mathrm{T}}=\mathrm{ATCC} 29320^{\mathrm{T}}$ ) & Zea mays leafhoppers & 46 \\
\hline I-4 & Rabbit tick spiroplasma & $277 \mathrm{~F}=\mathrm{ATCC} 29761)$ & Haemaphysalis leporispalustris & 25 \\
\hline I-5 & Green leaf bug spiroplasma & LB-12 = ATCC 33649) & Trigonotylus ruficornis & 22 \\
\hline I-6 & Spiroplasma insolitum & $\left.\mathrm{M}-55^{\mathrm{T}}=\operatorname{ATCC} 33502^{\mathrm{T}}\right)$ & Bidens sp. & 16 \\
\hline I-7 & Cocos spiroplasma & $\mathrm{N}-525=$ ATCC 33287) & Cocos nucifera & 11 \\
\hline I- 8 & Spiroplasma phoeniceum & $\mathrm{P}-40^{\mathrm{T}}=\mathrm{ATCC} 43115^{\mathrm{T}}$ ) & Catharanthus roseus & 31 \\
\hline III & Spiroplasma floricola & OBMG = ATCC 33221) & Insects, flowers & 10 \\
\hline IV & Spiroplasma apis & $\mathrm{B} 31^{\mathrm{T}}=$ ATCC $33834^{\mathrm{T}}$ ) & Apis mellifera & 23 \\
\hline $\mathrm{V}$ & Spiroplasma mirum & $\mathrm{SMCA}^{\mathrm{T}}=$ ATCC $29335^{\mathrm{T}}$ ) & Haemaphysalis leporispalustris & 40 \\
\hline VI & Spiroplasma ixodetis & $\left.\mathrm{Y} 32^{\mathrm{T}}=\operatorname{ATCC} 33835^{\mathrm{T}}\right)$ & Ixodes pacificus & 38 \\
\hline VII & Spiroplasma monobiae & $\mathrm{MQ}^{\mathrm{T}}=$ ATCC $\left.33825^{\mathrm{T}}\right)$, MMG, CUAS-1 & Monobia quadridens & 47 \\
\hline VIII-1 & Syrphid spiroplasma & $\mathrm{EA}-1=\mathrm{ATCC} 33826)$ & Eristalis arbustorum & 4 \\
\hline VIII-2 & Deerfly spiroplasma & $\mathrm{DF}-1=\mathrm{ATCC} 43209$ ) & Chrysops sp. & 7 \\
\hline IX & Spiroplasma clarkii & $\left.\mathrm{CN}-5^{\mathrm{T}}=\operatorname{ATCC} 33827^{\mathrm{T}}\right)$ & Cotinus nitida & 48 \\
\hline $\mathrm{X}$ & Spiroplasma culicicola & $\mathrm{AES}-1^{\mathrm{T}}=\mathrm{ATCC} 35112^{\mathrm{T}}$ ) & Aedes sollicitans & 17 \\
\hline XI & Spiroplasma velocicrescens & $\mathrm{MQ}^{\mathrm{T}}=\mathrm{ATCC} 35262^{\mathrm{T}}$ ) & Monobia quadridens & 20 \\
\hline XII & Cucumber beetle spiroplasma & DU-1 = ATCC 43210) & Diabrotica undecimpunctata & 5 \\
\hline XIII & Spiroplasma sabaudiense & $\mathrm{Ar}-1343^{\mathrm{T}}=\mathrm{ATCC} 43303^{\mathrm{T}}$ ) & Aedes sp. & 1 \\
\hline XV & Leafhopper spiroplasma & $\mathrm{I}-25=$ ATCC 43262) & Cicadulina bipunctella & 37 \\
\hline XVI-2 & Spiroplasma cantharicola & $\mathrm{CB}-1^{\mathbf{T}}=$ ATCC $43207^{\mathrm{T}}$ ) & Cantharis bilineatus & 45 \\
\hline XVIII & Tabanid spiroplasma & $\mathrm{TN}-1=\mathrm{ATCC} 43211)$ & Tabanus nigrovittatus & 7 \\
\hline XIX & Firefly spiroplasma & PUP-1 = ATCC 43206) & Photuris pennsylvanicus & 5 \\
\hline $\mathrm{XX}$ & Colorado potato beetle spiroplasma & $\mathrm{LD}-1=\mathrm{ATCC} 43213)$ & Leptinotarsa decemlineata & 4 \\
\hline XXI & Flower spiroplasma & $\mathrm{W} 115=\mathrm{ATCC} 43260)$ & Prunus sp. & 6 \\
\hline XXII & Spiroplasma taiwanense & $\mathrm{CT}-1^{\mathrm{T}}=\mathrm{ATCC} 43302^{\mathrm{T}}$ ) & Culex tritaeniorhynchus & 2 \\
\hline XXIV & Spiroplasma chinense & $\mathrm{CCH}^{\mathrm{T}}=\mathrm{ATCC} 43960^{\mathrm{T}}$ ) & Calystegia hederacea & 15 \\
\hline
\end{tabular}

products was the same as the size determined with nondigested linear molecules.

The sizes of spiroplasma chromosomes range from $940 \mathrm{kbp}$ for the smallest chromosome, the Spiroplasma monobiae $\mathrm{MQ}^{\mathrm{T}}{ }^{\mathrm{T}}$ (group VII) chromosome, to $2,220 \mathrm{kbp}$ for the largest chromosome, the Spiroplasma ixodetis $\mathrm{Y} 32^{\mathrm{T}}$ (group VI) chromosome. Thus, the genome of Spiroplasma ixodetis $\mathrm{Y}_{3} 2^{\mathrm{T}}$ appears to be more than twice as large as the genome of the spiroplasma with the smallest genome and is the largest genome described so far for a mollicute species. The genome of this organism is four times larger than the genome of the mollicute with the smallest genome, Mycoplasma genitalium $(9$, $35)$.

Figure 1 shows the distribution of genome sizes in different genera of the class Mollicutes. Genome sizes determined by PFGE are not available for members of the genera Asterole- plasma and Anaeroplasma. Many genome sizes fall in the range from 800 to $1,300 \mathrm{kbp}$. Only four Mycoplasma strains and five Ureaplasma strains have genomes that are smaller than 800 $\operatorname{kbp}(9,19,24,29,35)$. More than one-half of the Spiroplasma species, including all of the group I species, and most of the Acholeplasma species examined have genomes that are larger than $1,300 \mathrm{kbp}(24,29,41)$. In general, Spiroplasma and Acholeplasma species, which are considered phylogenetically "early" mollicutes, have larger genomes than Mycoplasma and Ureaplasma species, which are considered more "recent" mollicutes (42). This is consistent with the idea that Mollicutes evolved by regressive evolution (i.e., by genome losses).

In view of the results presented above and elsewhere, it is clear that in the class Mollicutes, genome size heterogeneity occurs at every level of classification. This is particularly true within genera; in one genus certain species may have genomes

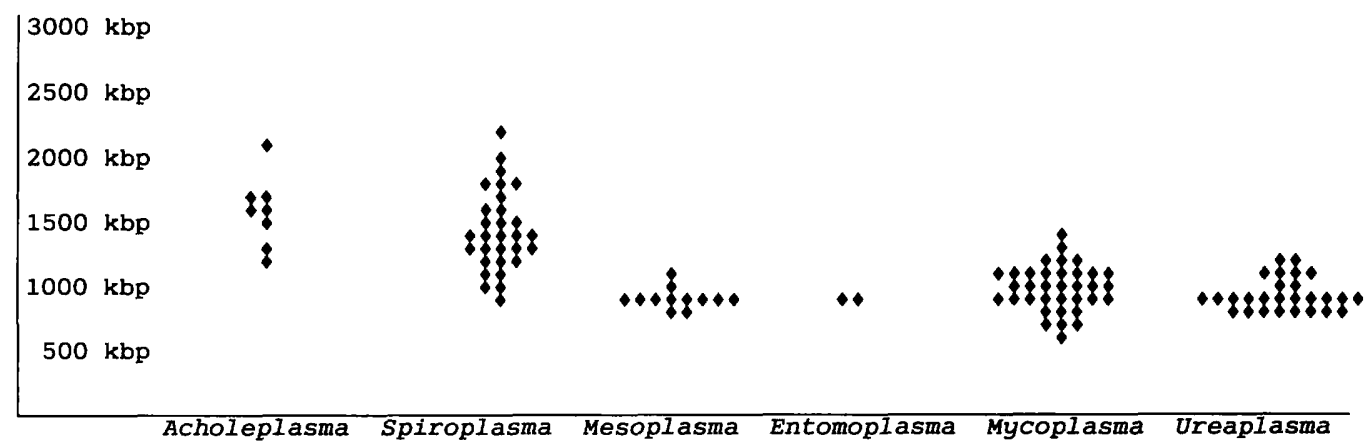

FIG. 1. Distribution of genome sizes within the class Mollicutes. Each diamond represents a mollicute species. Data are from this study and references 9,13 , 14, $19,21,26,28,29,35,39,41,49,52$, and 53 . 
TABLE 2. Genome sizes of Spiroplasma spp.

\begin{tabular}{|c|c|c|c|}
\hline \multirow[b]{2}{*}{$\begin{array}{l}\text { Group or } \\
\text { subgroup }\end{array}$} & \multirow[b]{2}{*}{ Strain } & \multicolumn{2}{|c|}{ Genome size (kbp) } \\
\hline & & $\begin{array}{c}\text { Undigested } \\
\text { linear } \\
\text { molecule }\end{array}$ & $\begin{array}{l}\text { Sum of NotI } \\
\text { restriction } \\
\text { fragment } \\
\text { sizes }\end{array}$ \\
\hline $\mathrm{I}-1$ & Spiroplasma citri $\mathrm{R} 8 \mathrm{~A} 2^{\mathrm{T}}$ & $1,820^{a}$ & $1,820^{a}$ \\
\hline $\mathrm{I}-2$ & Spiroplasma melliferum $\mathrm{BC}-3^{\mathrm{T}}$ & $1,460^{a}$ & $1,460^{a}$ \\
\hline I-3 & Spiroplasma kunkelii E-275 & 1,610 & 1,580 \\
\hline $\mathrm{I}-4$ & Spiroplasma sp. strain $277 \mathrm{~F}$ & 1,620 & 1,580 \\
\hline I-5 & Spiroplasma sp. strain LB-12 & 2,020 & $\mathrm{ND}^{b}$ \\
\hline I-6 & Spiroplasma insolitum $\mathrm{M}-55^{\mathrm{T}}$ & 1,810 & 1,760 \\
\hline I-7 & Spiroplasma sp. strain N-525 & 1,780 & ND \\
\hline I-8 & Spiroplasma phoeniceum $\mathrm{P}-40^{\mathrm{T}}$ & 1,860 & 1,840 \\
\hline III & Spiroplasma floricola OBMG & 1,270 & 1,325 \\
\hline IV & Spiroplasma apis $\mathrm{B} 31^{\mathrm{T}}$ & $1,300^{c}$ & ND \\
\hline V & Spiroplasma mirum $\mathrm{SMCA}^{\mathrm{T}}$ & 1,300 & 1,270 \\
\hline VI & Spiroplasma ixodetis $\mathrm{Y}^{3} 2^{\mathrm{T}}$ & 2,220 & 2,220 \\
\hline \multirow[t]{3}{*}{ VII } & Spiroplasma monobiae $\mathrm{MQ1}^{\mathrm{T}}$ & 940 & 980 \\
\hline & Spiroplasma monobiae MMG & 995 & ND \\
\hline & Spiroplasma monobiae CUAS-1 & 1,080 & ND \\
\hline VIII-1 & Spiroplasma sp. strain EA-1 & 1,230 & 1,150 \\
\hline VIII-2 & Spiroplasma sp. strain DF-1 & 1,270 & 1,250 \\
\hline IX & Spiroplasma clarkii $\mathrm{CN}-5^{\mathrm{T}}$ & 1,720 & 1,660 \\
\hline $\mathrm{X}$ & Spiroplasma culicicola AES-1 ${ }^{\mathrm{T}}$ & 1,350 & 1,320 \\
\hline XI & Spiroplasma sp. strain MQ4 & 1,480 & ND \\
\hline XII & Spiroplasma sp. strain DU-1 & 1,350 & 1,280 \\
\hline XIII & Spiroplasma sabaudiense Ar- $1343^{\mathrm{T}}$ & 1,175 & 1,095 \\
\hline XV & Spiroplasma sp. strain I-25 & 1,380 & 1,340 \\
\hline XVI-2 & Spiroplasma cantharicola $\mathrm{CB}-1^{\mathrm{T}}$ & 1,320 & 1,320 \\
\hline XVIII & Spiroplasma sp. strain TN-1 & 1,370 & 1,390 \\
\hline XIX & Spiroplasma sp. strain PUP-1 & 1,375 & 1,350 \\
\hline $\mathrm{XX}$ & Spiroplasma sp. strain LD-1 & 1,085 & ND \\
\hline XXI & Spiroplasma sp. strain W115 & 980 & 1,000 \\
\hline XXII & Spiroplasma taiwanense $\mathrm{CT}-1^{\mathrm{T}}$ & 1,195 & 1,220 \\
\hline XXIV & Spiroplasma chinense $\mathrm{CCH}^{\mathrm{T}}$ & 1,530 & 1,580 \\
\hline
\end{tabular}

${ }^{a}$ Data from reference 52 .

${ }^{b} \mathrm{ND}$, not determined.

${ }^{c}$ Data from reference 13 .

that are twice as large as the genomes of other species. Genome size heterogeneity also occurs at the species level; in Ureaplasma urealyticum, Mycoplasma mycoides, Mycoplasma hominis, and Spiroplasma citri, variations of up to $30 \%$ in genome size have been observed for different strains of the same species $(21,29,49,51)$.

\section{REFERENCES}

1. Abalain-Colloc, M. L., C. Chastel, J. G. Tully, J. M. Bové, R. F. Whitcomb, B. Gilot, and D. L. Williamson. 1987. Spiroplasma sabaudiense sp. nov. from mosquitoes collected in France. Int. J. Syst. Bacteriol. 37:260-265.

2. Abalain-Colloc, M. L., L. Rosen, J. G. Tully, J. M. Bové, C. Chastel, and D. L. Williamson. 1988. Spiroplasma taiwanense sp. nov., a new species from Culex tritaeniorhynchus mosquitoes collected in Taiwan. Int. J. Syst. Bacteriol. 38:103-107.

3. Abalain-Colloc, M. L., D. L. Williamson, P. Carle, J. H. Abalain, J. G. Tully, F. Bonnet, M. Konai, R. F. Whitcomb, J. M. Bové, and C. Chastel. 1993. Division of group XVI spiroplasmas into subgroups. Int. J. Syst. Bacteriol. 43:342-346.

4. Clark, T. B. 1982. Spiroplasmas: diversity of arthropod reservoirs and host-parasite relationships. Science 217:57-59.

5. Clark, T. B. 1984. Diversity of spiroplasma host-parasite relationships. Isr. J. Med. Sci. 20:995-997.

6. Clark, T. B., R. B. Henegar, L. Rosen, K. J. Hackett, R. F. Whitcomb, J. E. Lowry, C. Saillard, J. M. Bové, J. G. Tully, and D. L. Williamson. 1987. New spiroplasmas from insects and flowers: isolation, ecology, and host association. Isr. J. Med. Sci. 23:687-690

7. Clark, T. B., B. V. Peterson, R. F. Whitcomb, R. B. Henegar, K. J. Hackett, and J. G. Tully. 1984. Spiroplasmas in the Tabanidae. Isr. J. Med. Sci. 20:1002-1005.

8. Clark, T. B., R. F. Whitcomb, J. G. Tully, C. Mouches, C. Saillard, J. M. Bové, H. Wroblewski, P. Carle, D. L. Rose, R. B. Henegar, and D. L.
Williamson. 1985. Spiroplasma melliferum, a new species from the honeybee (Apis mellifera). Int. J. Syst. Bacteriol. 35:296-308.

9. Colman, S. D., P. C. Hu, W. Litaker, and K. F. Bott. 1990. A physical map of the Mycoplasma genitalium genome. Mol. Microbiol. 4:683-687.

10. Davis, R. E., I. M. Lee, and J. F. Worley. 1981. Spiroplasma floricola, a new species isolated from surfaces of flowers of the tulip tree, Liriodendron tulipifera L. Int. J. Syst. Bacteriol. 31:456-464.

11. Eden-Green, S. J., and H. Waters. 1981. Isolation and preliminary characterization of a spiroplasma from coconut palm in Jamaica. J. Gen. Microbiol. 124:263-270.

12. Gasparich, G. E., C. Saillard, E. A. Clark, M. Konai, F. E. French, J. G. Tully, K. J. Hackett, and R. F. Whitcomb. 1993. Serologic and genomic relatedness of group VIII and group XVII spiroplasmas and subdivision of spiroplasma group VIII into subgroups. Int. J. Syst. Bacteriol. 43:338-341.

13. Grau, O. 1991. Ph.D. thesis. Université de Bordeaux II, Bordeaux, France.

14. Grau, O., F. Laigret, P. Carle, J. G. Tully, D. L. Rose, and J. M. Bové. 1991. Identification of a plant-derived mollicute as a strain of an avian pathogen, Mycoplasma iowae, and its implications for mollicute taxonomy. Int. J. Syst. Bacteriol. 41:473-478.

15. Guo, Y. H., T. A. Chen, R. F. Whitcomb, D. L. Rose, J. G. Tully, D. L. Williamson, X. D. Ye, and Y. X. Chen. 1990. Spiroplasma chinense sp. nov. from flowers of Calystegia hederacea in China. Int. J. Syst. Bacteriol. 40:421-425.

16. Hackett, K. J, R. F. Whitcomb, J. G. Tully, D. L. Rose, P. Carle, J. M. Bové, R. B. Henegar, T. B. Clark, E. A. Clark, M. Konai, J. R. Adams, and D. L. Williamson. 1993. Spiroplasma insolitum sp. nov., a new species of group I spiroplasma with an unusual DNA base composition. Int. J. Syst. Bacteriol. 43:272-277.

17. Hung, S. Y., T. A. Chen, R. F. Whitcomb, J. G. Tully, and X. Y. Chen. 1987. Spiroplasma culicicola sp. nov. from the salt marsh mosquito Aedes sollicitans. Int. J. Syst. Bacteriol. 37:365-370.

18. Junca, P., C. Saillard, J. G. Tully, O. Garcia-Jurado, J. R. Degorce-Dumas, C. Mouchès, J. C. Vignault, and R. Vogel. 1980. Caractérisation de spiroplasmes isolés d'insectes et de fleurs de France continentale, de Corse et du Maroc. Proposition pour une classification des spiroplasmes. C. R. Acad. Sci. Ser. D 290:1209-1212.

19. Kakulphimp, J., L. R. Finch, and J. A. Robertson. 1991. Genome sizes of mammalian and avian ureaplasmas. Int. J. Syst. Bacteriol. 41:326-327.

20. Konai, M., R. F. Whitcomb, J. G. Tully, D. L. Rose, P. Carle, J. M. Bové, R. B. Henegar, K. J. Hackett, T. B. Clark, and D. L. Williamson. Spiroplasma velocicrescens sp. nov., a new species from the vespid wasp Monobia quadridens. Submitted for publication.

21. Ladefoged, S. A., and G. Christiansen. 1992. Physical and genetic mapping of the genomes of five Mycoplasma hominis strains by pulsed-field gel electrophoresis. J. Bacteriol. 174:2199-2207.

22. Lei, J. D., H. J. Su, and T. A. Chen. 1979. Spiroplasmas isolated from green leaf bug Trigonotylus ruficornis Geoffroy, p. 89-97. In Proceedings of the US-ROC Plant Mycoplasma Seminar. National Science Council, Taipei, Taiwan.

23. Mouchès, C., J. M. Bové, J. G. Tully, D. L. Rose, R. E. McCoy, P. Carle Junca, M. Garnier, and C. Saillard. 1983. Spiroplasma apis, a new species from the honey bee Apis mellifera. Ann. Inst. Pasteur Microbiol. 134:383397.

24. Neimark, H. C., and C. S. Lange. 1990. Pulse-field electrophoresis indicates full-length mycoplasma chromosomes range widely in size. Nucleic Acids Res. 18:5443-5448.

25. Pickens, E. G., R. K. Gerloff, and W. Burgdorfer. 1968. Spirochete from the rabbit tick, Haemaphysalis leporispalustris (Packard). J. Bacteriol. 95:291299

26. Pyle, L. E., L. N. Corcoran, B. J. Cocks, A. D. Bergemann, J. C. Whitley, and L. R. Finch. 1988. Pulsed-field electrophoresis indicates larger than expected sizes for mycoplasma genomes. Nucleic Acids Res. 16:6015-6025.

27. Pyle, L. E., and L. R. Finch. 1988. Preparation and FIGE separation of infrequent restriction fragments from Mycoplasma mycoides DNA. Nucleic Acids Res. 16:226-228.

28. Pyle, L. E., and L. R. Finch. 1988. A physical map of the genome of Mycoplasma mycoides subspecies mycoides $\mathrm{Y}$ with some functional loci. Nucleic Acids Res. 16:6027-6040.

29. Robertson, J. A., L. E. Pyle, G. W. Stemke, and L. R. Finch. 1990. Human ureaplasmas show diverse sizes by pulsed-field electrophoresis. Nucleic Acids Res. 18:1451-1455.

30. Saglio, P., M. Lhospital, D. Lafleche, G. Dupont, J. M. Bové, J. G. Tully, and E. A. Freundt. 1973. Spiroplasma citri gen. and sp. n.: a mycoplasma-like organism associated with "stubborn" disease of citrus. Int. J. Syst. Bacteriol. 23:191-204.

31. Saillard, C., J. C. Vignault, J. M. Bové, A. Raie, J. G. Tully, D. L. Williamson, A. Fos, M. Garnier, A. Gadeau, P. Carle, and R. F. Whitcomb. 1987. Spiroplasma phoeniceum sp. nov., a new plant-pathogenic species from Syria. Int. J. Syst. Bacteriol. 37:106-115.

32. Schwartz, D. C., and C. R. Cantor. 1984. Separation of yeast chromosomesized DNAs by pulsed field gradient gel electrophoresis. Cell 37:67-75.

33. Smith, C. L., and G. Condemine. 1990. New approaches for physical 
mapping of small genomes. J. Bacteriol. 172:1167-1172.

34. Smith, C. L., S. Klco, and C. R. Cantor. 1988. Pulsed field gel electrophoresis and the technology of large DNA molecules, p. 41-72. In K. Davies (ed.), Genome analysis: a practical approach. IRL Press, Oxford.

35. Su, C. J., and J. B. Baseman. 1990. Genome size of Mycoplasma genitalium. J. Bacteriol. 172:4705-4707.

36. Tully, J. G., J. M. Bové, F. Laigret, and R. F. Whitcomb. 1993. Revised taxonomy of the class Mollicutes: proposed elevation of a monophyletic cluster of arthropod-associated mollicutes to ordinal rank (Entomoplasmatales, ord. nov.), with provision for familial rank to separate species with nonhelical morphology (Entomoplasmataceae, fam. nov.) from helical species (Spiroplasmataceae), and emended descriptions of the order Mycoplasmatales, family Mycoplasmataceae. Int. J. Syst. Bacteriol. 43:378-385.

37. Tully, J. G., D. L. Rose, E. Clark, P. Carle, J. M. Bové, R. B. Henegar, R. F. Whitcomb, D. E. Colflesh, and D. L. Williamson. 1987. Revised group classification of the genus Spiroplasma (class Mollicutes), with proposed new groups XII through XXIII. Int. J. Syst. Bacteriol. 37:357-364

38. Tully, J. G., D. L. Rose, C. E. Yunker, P. Carle, J. M. Bové, D. L. Williamson, and R. F. Whitcomb. 1995. Spiroplasma ixodetis sp. nov., a new species from Ixodes pacificus ticks collected in Oregon. Int. J. Syst. Bacteriol. 45:23-28.

39. Tully, J. G., R. F. Whitcomb, K. J. Hackett, D. L. Rose, R. B. Henegar, J. M. Bové, P. Carle, D. L. Williamson, and T. B. Clark. 1994. Taxonomic descriptions of eight new non-sterol-requiring mollicutes assigned to the genus Mesoplasma. Int. J. Syst. Bacteriol. 44:685-693.

40. Tully, J. G., R. F. Whitcomb, D. L. Rose, and J. M. Bové. 1982. Spiroplasma minum, a new species from rabbit tick (Haemaphysalis leporispalustris). Int. J. Syst. Bacteriol. 32:92-100.

41. Tully, J. G., R. F. Whitcomb, D. L. Rose, J. M. Bové, P. Carle, N. L. Somerson, D. L. Williamson, and S. Eden-Green. 1994. Acholeplasma brassicae sp. nov. and Acholeplasma palmae sp. nov., two non-sterolrequiring mollicutes from plant surfaces. Int. J. Syst. Bacteriol. 44:680-684.

42. Weisburg, W. G., J. G. Tully, D. L. Rose, J. P. Petzel, H. Oyaizu, D. Yang, L. Mandelco, J. Sechrest, T. G. Lawrence, J. Van Etten, J. Maniloff, and C. R. Woese. 1989. A phylogenetic analysis of the mycoplasmas: basis for their classification. J. Bacteriol. 171:6455-6467.

43. Whitcomb, R. F. 1983. Culture media for spiroplasmas, p. 147-159. In S.
Razin and J. G. Tully (ed.), Methods in mycoplasmology. Academic Press, New York.

44. Whitcomb, R. F., J. M. Bové, T. A. Chen, J. G. Tully, and D. L. Williamson 1987. Proposed criteria for an interim serogroup classification for members of the genus Spiroplasma (class Mollicutes). Int. J. Syst. Bacteriol. 37:82-84.

45. Whitcomb, R. F., C. Chastel, M. Abalain-Colloc, C. Stevens, J. G. Tully, D. L. Rose, P. Carle, J. M. Bové, J. R. B. Henegar, K. J. Hackett, T. B. Clark, M. Konai, and D. L. Williamson. 1993. Spiroplasma cantharicola sp. nov., from cantharid beetles (Coleoptera: Cantharidae). Int. J. Syst. Bacteriol. 43:421424.

46. Whitcomb, R. F., T. A. Chen, D. L. Williamson, C. Liao, J. G. Tully, J. M. Bové, C. Mouchès, D. L. Rose, M. E. Coan, and T. B. Clark. 1986. Spiroplasma kunkelii sp. nov.: characterization of the etiological agent of corn stunt disease. Int. J. Syst. Bacteriol. 36:170-178.

47. Whitcomb, R. F., J. G. Tully, D. L. Rose, P. Carle, J. M. Bové, R. B. Henegar, K. J. Hackett, T. B. Clark, M. Konai, J. Adams, and D. L. Williamson. 1993. Spiroplasma monobiae sp. nov. from the vespid wasp Monobia quadridens (Hymenoptera: Vespidae). Int. J. Syst. Bacteriol. 43:256-260.

48. Whitcomb, R. F., J. C. Vignault, J. G. Tully, D. L. Rose, P. Carle, J. M. Bové, K. J. Hackett, R. B. Henegar, M. Konai, and D. L. Williamson. 1993. Spiroplasma clarkii sp. nov. from the green june beetle (Coleoptera: Scarabaeidae). Int. J. Syst. Bacteriol. 43:261-265.

49. Whitley, J. C. 1991. Ph.D. thesis. University of Melbourne, Melbourne, Australia.

50. Williamson, D. L., J. G. Tully, and R. F. Whitcomb. 1989. The genus Spiroplasma, p. 71-111. In M. F. Barile, S. Razin, J. G. Tully, and R. F. Whitcomb (ed.), The mycoplasmas, vol. 5. Academic Press, Inc., San Diego, Calif.

51. Ye, F. Ph.D. thesis. Université de Bordeaux II, Bordeaux, France.

52. Ye, F., F. Laigret, and J. M. Bové. 1994. A physical map of the prokaryote Spiroplasma melliferum and its comparison with the Spiroplasma citri map. C. R. Acad. Sci. 317:392-398.

53. Ye, F., F. Laigret, J. C. Whitley, C. Citti, L. R. Finch, P. Carle, J. Renaudin, and J. M. Bové. 1992. A physical and genetic map of the Spiroplasma citri genome. Nucleic Acids Res. 20:1559-1565. 